\title{
GCU
}

Glasgow Caledonian

University

University for the Common Good

\section{Protective effect of carnosic acid against acrylamide-induced toxicity in RPE cells}

Albalawi, Aishah Eis S; Alhasani, Reem Hasaballah A.; Biswas, Lincoln; Reilly, James; Shu, Xinhua

Published in:

Food and Chemical Toxicology

DOI:

10.1016/j.fct.2017.01.026

Publication date:

2017

Document Version

Author accepted manuscript

Link to publication in ResearchOnline

Citation for published version (Harvard):

Albalawi, AES, Alhasani, RHA, Biswas, L, Reilly, J \& Shu, X 2017, 'Protective effect of carnosic acid against acrylamide-induced toxicity in RPE cells', Food and Chemical Toxicology, vol. 108, no. Part B, pp. 543-553. https://doi.org/10.1016/j.fct.2017.01.026

\section{General rights}

Copyright and moral rights for the publications made accessible in the public portal are retained by the authors and/or other copyright owners and it is a condition of accessing publications that users recognise and abide by the legal requirements associated with these rights.

Take down policy

If you believe that this document breaches copyright please view our takedown policy at https://edshare.gcu.ac.uk/id/eprint/5179 for details of how to contact us. 
2 Aishah Albalawi ${ }^{1,2}$, Reem Hasaballah A Alhasani ${ }^{1,3}$, Lincoln Biswas ${ }^{1}$, James Reilly ${ }^{1}$, Xinhua $3 \mathrm{Shu}^{1}$

4

51 Department of Life Sciences, Glasgow Caledonian University, Cowcaddens Rd, G4 OBA,

6 Glasgow, UK

72 Department of Biology, University of Tabuk, Tabuk, Saudi Arabia

83 Department of Biology, Umm Al-Qura University, Makkah, Saudi Arabia

\section{Correspondence author}

Dr Xinhua Shu, Department of Life Sciences, Glasgow Caledonian University, Glasgow G4 OBA, UK. Tel: 0044141 4418763; Email: Xinhua.Shu@gcu.ac.uk 


\section{Abstract}

Acrylamide is a substance that can be neurotoxic in humans and experimental animals. It is formed at different rates in starchy foods cooked at temperatures above $120^{\circ} \mathrm{C}$ as a result of interaction between monosaccharides and the amino acid asparagine. Carnosic acid accounts for over $90 \%$ of the antioxidant properties of rosemary extract and is a powerful inhibitor of lipid peroxidation in microsomal and liposomal systems. Carnosic acid has been shown to protect against oxidative and inflammatory effects. In order to investigate the protective properties of carnosic acid against acrylamide-induced toxicity in human retinal pigment epithelium (RPE) cells, ARPE-19 cells were pre-treated with $10 \mu \mathrm{M}$ CA for $24 \mathrm{~h}$ followed by treatment with acrylamide $(0.7$ or $1 \mathrm{mM})$ for $24 \mathrm{~h}$. ARPE-19 cells pre-treated with $10 \mu \mathrm{M}$ carnosic acid showed significantly increased cell viability and decreased cell death rate when compared to ARPE-19 cells treated with acrylamide alone. Activities of SOD and catalase and the level of GSH and expression of NRF2 and a number of anti-oxidant genes were significantly decreased in ARPE-19 cells, while there were significant increases in ROS and MDA; pre-treatment with carnosic acid significantly counteracted these changes. Our results suggest that carnosic acid protected RPE cells from acrylamide-induced toxicity.

Key words Acrylamide, carnosic acid, neurotoxicity, oxidative damage, retinal pigment epithelium cells (1)

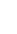
54 55 36 


\section{Introduction}

Acrylamide (Fig. 1E) is a highly water-soluble white substance with a solid crystalline form (Becalski et al., 2003; Exon, 2006). The main application of acrylamide and polyacrylamides is in the manufacture of plastics and in the welding of waterpipes, although they are also used in the production of paper and textiles. In addition, acrylamide monomer is used in the preparation of polyacrylamide electrophoresis gels in research and clinical diagnosis labs (Dybing et al., 2005). Acrylamide is also formed in starchy foods such as fried potatoes, bread, cookies, and coffee heated to temperatures above $120^{\circ} \mathrm{C}$ (Tareke et al., 2002; Kahkeshani et al., 2015). Generally, the formation of acrylamide during cooking at high temperatures is due to the reaction between the amino acid asparagine and a carbonylcontaining source (Zyzak et al., 2003). Jakobsen et al. (2016) estimated that the mean dietary intake of acrylamide in the Danish population is $0.27 \mu \mathrm{g} / \mathrm{kg}$ bw/day (females) and 0.36 $\mu \mathrm{g} / \mathrm{kg}$ bw/day (males). Two earlier studies estimated that the Dutch population had a slightly higher mean acrylamide exposure of 0.48 (Konings et al., 2003) and 0.5 (Boon et al., 2005) $\mu \mathrm{g} / \mathrm{kg}$ bw/day. Similar to that of the Dutch population, the US population had an estimated mean acrylamide exposure of $0.44 \mu \mathrm{g} / \mathrm{kg}$ bw/day (Doerge et al., 2008). The major contribution to dietary intake of acrylamide is French-fries /fried potatoes (Boon et al., 2005; Doerge et al., 2008; Dybing and Sanner, 2003; Jakobsen et al., 2016; Svensson et al., 2003). Acrylamide is classified as a potential carcinogen, one possible reason being its genotoxicity (Dobrovolsky et al., 2016; EFSA, 2015; Meil et al., 2008; Mei et al., 2010). Rodents with oral exposure to acrylamide experienced tumours in various organs (EFSA, 2015) while humans exposed to acrylamide have an increased risk of developing cancer (EFSA, 2015).

Acrylamide was identified as a neurotoxin about 60 years ago (Kuperman, 1958). Humans and laboratory animals exposed to acrylamide exhibited neurotoxicity characterised by ataxia, weight loss, skeletal muscle weakness, and distal swelling and degeneration of axons in the peripheral and central nervous systems (LoPachin and Decaprio, 2005; ElTantawi, 2007). The retina is a part of the central nervous system and contains three main 
layers: photoreceptor layer, inner nuclear layer and ganglion cell layer (Patnaik et al, 2015). The retina is responsible for receiving light and converting it to neural signals that are passed to the brain for visual processing. Early studies showed that chronic exposure of monkeys (Macaca nemestrina) to acrylamide led to significantly reduced visual function (Merigan et al., 1985) and degeneration of ganglion cells, although the inner nuclear and photoreceptor layers were preserved (Eskin et al., 1985; Eskin and Merigan, 1986). Maternal exposure of rat to acrylamide caused massive structural abnormalities in outer and inner nuclear layers and degeneration of ganglion cells in retinas of offspring at age 7 and 14 days (Sakr et al., 2011). Adult rats administered with acrylamide (15 mg/kg body weight) for 28 days exhibited a significant reduction in amplitude of electroretinogram a and b waves (Ali et al., 2014).

Carnosic acid (Fig. 1E) is a phenolic diterpene extracted from rosemary (Rosmarinus officinalis) and has shown antioxidative activity (Aruoma et al., 1992; Wu et al., 2015), antiinflammatory activity (Lin et al., 2014), anticarcinogenic activity (Cortese et al., 2016; Russo et al., 2009), and antibacterial activity (Vázquez et al., 2016). Carnosic acid is characterized by its lipid solubility and its expulsion of free radicals of oxygen, hydroxyl, and lipid peroxyl. Therefore, it prevents the oxidation of lipids and the rupture of biological membranes (Aruoma et al., 1992; Haraguchi et al., 1995). It has been reported that carnosic acid prevents the accumulation of the protein cysteine and reduces meta-fat oxidation, thus slowing the rate of free radical formation and thereby protecting cells from damage (Poeckel et al., 2008; Sozio et al., 2008). Additionally, carnosic acid has been reported to induce the transcriptional activation of antioxidant Nrf2/ARE pathway, which may be involved in the protective effects of carnosic acid in chronic neurodegenerative conditions like Parkinson's disease (Bahri et al., 2016).

Retinal pigment epithelium (RPE) cells lie beneath the photoreceptor layer in the retina and maintain the function of photoreceptors by helping to renew photoreceptor outer segments and by providing nutrition to photoreceptors (Strauss, 2005). In the current study we investigated the toxicity of acrylamide to RPE cells and evaluated the protective effects of carnosic acid against acrylamide-induced toxicity. 


\section{Materials and methods}

\subsection{Cell Culture}

Adult human retinal pigment epithelium ARPE-19 cells $\left(\right.$ ATCC $^{\circledR}$ CRL-2302 ${ }^{\mathrm{TM}}$ ) were grown in Dulbecco's Modified Eagle Medium (DMEM/F12, Lonza, UK) comprising 2.4 mM LGlutamine, 17.5mM glucose, and supplemented with 10\% fetal bovine serum (FBS, Lonza), $100 \mu \mathrm{g} / \mathrm{mL}$ streptomycin, and 100 units $/ \mathrm{mL}$ penicillin (Lonza, UK) and $0.26 \%$ sodium bicarbonate (Sigma).

\subsection{Cell viability}

ARPE-19 cells were seeded in a clear 6-well tissue culture plate (Greiner Bio One, UK) for 24 hours at a density of $3 \times 10^{5}$ cells/well. To test cytoprotective effects of carnosic acid to acrylamide-induced cell death, cells were pretreated with $10 \mu \mathrm{M}$ of carnosic acid (Cat. Number C0609, purity>91\%, Sigma) dissolved in Dimethyl sulfoxide (DMSO, Sigma) for 24 hours in serum-free medium. Cells were then treated with acrylamide $(0.7$ and $1 \mathrm{mM})$ for 24 hours. Cells were stained with $0.2 \%$ crystal violet (Sigma, UK). The absorbance was measured at 570nm in a microplate spectrophotometer Epoch reader (Biotech, UK). The percentage of viable cells was determined using the following formula:

$\%$ of viable cells $=[($ absorbance of untreated cells - absorbance of treated cells $) /$ absorbance of untreated cells] $\times 100$.

\subsection{Measurement of reactive oxygen species (ROS)}

ARPE-19 cells $(25,000 /$ well) were seeded in clear-bottomed black 96 -well tissue culture plates (Greiner Bio One, UK) and cultured for 24 hours. Cells were then treated with carnosic acid $(10 \mu \mathrm{M})$, while control cells were treated with $0.1 \%$ DMSO alone for 24 hours. Cells were washed twice with PBS (200 $\mu \mathrm{l} /$ well $)$, then treated with acrylamide $(0.7$ and $1 \mathrm{mM})$ for 24 hours. Total ROS was measured using the 6-Carboxy-2',7'-Dichlorofluorescin diacetate (DCFH-DA) (Sigma, UK) according to the manufacturer's guidelines. Briefly, a stock solution of $10 \mathrm{mM}$ of DCFH-DA was prepared in DMSO, then cells were incubated with $10 \mu \mathrm{M} \mathrm{DCFH}-$ 


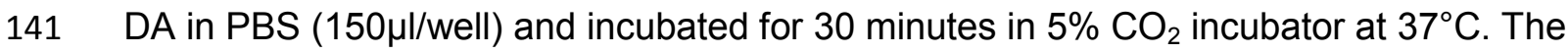

142 fluorescence was measured at $485 \mathrm{~nm}$ (excitation) and $525 \mathrm{~nm}$ (emission) using a Fluostar

143 Optima microplate reader (BMG-labtech)

2.4 Quantitative real-time polymerase chain reaction (qRT-PCR)

146 Total RNA was isolated using Trizol Reagent (Sigma, UK) according to the manufacturer's

147 protocol. cDNA was synthesized using a High-Capacity cDNA Reverse Transcription Kit with

148 RNase Inhibitor (Applied Biosystems, UK). The quantification of gene expression was

149 detected by qRT-PCR assay using a Platinum ${ }^{2}$ SYBR $®$ Green QPCR SuperMix-UDG

150 w/ROX kit (Invitrogen, UK). The relative change in gene expression was determined

151 according to $2^{-\Delta \Delta C T}$ formula (Livak and Schmittgen, 2001) in which gene expression was

152 normalized to expression of the housekeeping gene, $\beta$-actin, in the treated and control

153 samples. The sequences of primers used in qRT-PCR are listed in Table 1.

2.5. Measurement of catalase (CAT) and superoxide dismutase (SOD) activities

CAT and SOD activities were detected in ARPE-19 cells using the SOD Detection Kit

(OxiSelect Superoxide Dismutase Activity Assay Kit; Cell Biolabs, STA-340) and the

OxiSelect Catalase Activity Assay Kit (Cell Biolabs, STA-341), according to the manufacturer's instructions.

\subsection{Quantification of glutathion and malondialdehyde}

Quantitation of glutathion (GSH) and malondialdehyde (MDA) in treated and control ARPE19 cells was measured using the total glutathion (GSSG/GSH) assay kit (Cell Biolabs, STA312) and TBARS Assay kit ( for MDA) (Cell Biolabs, STA-330) according to the manufacturer's instructions. 


\subsection{Western blotting assay}

170 Control and treated ARPE-19 cells were lysed with ice-cold RIPA lysis buffer (Thermo

171 Scientific), the lysates were collected and centrifuged, and the supernatants were stored at $172-80^{\circ} \mathrm{C}$ until required. Protein concentration was determined using Precision Red Advanced 173 Protein Assay reagent (Cytoskeleton, Inc. Cat. \# ADV02-A) according to the manufacturer's guidelines. Proteins were run in SDS-PAGE and transferred to nitrocellulose membrane 175 (Amersham Biosciences). The membrane was blocked by incubation in $5 \%$ milk powder in 176 Tris-Buffered Saline-Tween 20 buffer for 1 hour at room temperature, followed by incubation with primary antibodies (GAPDH and NRF2, 1:1000 dilution) overnight at $4^{\circ} \mathrm{C}$. The membrane was washed and incubated with secondary antibodies (1:10000 dilution). The signals were detected using the LI-COR Odyssey FC Imaging System and the signal intensity was analyzed by Image Studio ${ }^{\mathrm{TM}}$ Lite analysis software (LI-COR).

\subsection{Detection of cell death}

Cell death was detected using DeadEnd ${ }^{\mathrm{TM}}$ fluorometric TUNEL assay kit (Promega) following the manufacturer's instructions. Briefly, treated and control ARPE1-9 cells were fixed with $4 \%$ PFA for 20 minutes at $4^{\circ} \mathrm{C}$ and washed with PBS once, followed by permeabilisation with $0.2 \%$ Triton $\mathrm{X}-100$ in PBS for 5 min. Cells were labelled with rTDT reaction mix for one hour at $37^{\circ} \mathrm{C}$ and the reaction was stopped with $2 \mathrm{X}$ SSC. Cells were rinsed with PBS and mounted using Vectashield mounting media containing DAPI (Vector laboratories). Images were captured using ZEISS LSM 800 confocal microscopy. To quantify cell death, the number of TUNEL positive cells in 300 cells was counted from three individual samples (100 cells in each sample).

\subsection{Statistical Analysis}

194 Statistical analysis was carried out using GraphPad Prism 6 software. All data were obtained 195 from three independent experiments using one-way ANOVA test. Data are presented as means \pm standard error. 


\section{Results}

\subsection{Acrylamide treatment resulted in decreased RPE cell viability that was} significantly counteracted by carnosic acid

200

201

202

203

204

To investigate the effect of acrylamide-induced toxicity in RPE cells, cell viability was assessed by crystal violet staining (Fig. 1D). Cell viability of ARPE-19 cells was significantly decreased to $65.55 \%, 50.05 \%$, and $36.37 \%$ of untreated levels following exposure to 0.7 , 1.0, or $2.0 \mathrm{mM}$ acrylamide respectively (Fig. 1A). ARPE-19 exposed to acrylamide at 0.37 and $0.5 \mathrm{mM}$ showed no significant reduction in cell viability. Prior to investigating the protective effect of carnosic acid on acrylamide exposure, we assessed cell viability of ARPE-19 cells treated with carnosic acid at 10, 20, 30, 40, 50, and $60 \mu \mathrm{M}$ and found that cell viability was significantly decreased when treated with carnosic acid of 40,50 or $60 \mu \mathrm{M}$ but was not significantly changed when treated with carnosic acid at 10,20 or $30 \mu \mathrm{M}$ (Fig. 1B). Consequently, acrylamide at concentrations of 0.7 and $1.0 \mathrm{mM}$ and carnosic acid at concentration of $10 \mu \mathrm{M}$ were used for subsequent experiments. ARPE-19 cells first treated with carnosic acid $(10 \mu \mathrm{M})$ for $24 \mathrm{~h}$ and then exposed to 0.7 or $1 \mathrm{mM}$ acrylamide for $24 \mathrm{~h}$ demonstrated significantly increased cell viability by $12.21 \%$ and $14.25 \%$ respectively when compared with cells treated with acrylamide alone (Fig. 1 C, D).

\subsection{Carnosic acid protects against acrylamide-induced cell death in RPE cells}

We examined whether reduced cell viability is associated with apoptotic cell death. We used TUNEL staining to assess the cell death (Fig. 2A) and found that there was a significantly increased cell death rate in ARPE-19 cells exposed to 0.7 and $1 \mathrm{mM}$ acrylamide when compared to untreated control cells and that pre-treatment with carnosic acid led to significant reduction in cell death induced by acrylamide (Fig. 2B).

We also measured the expression of cell death related genes, caspase- 3 and caspase- 9 (Fig. 3). Acrylamide treatment $(0.7$ and $1 \mathrm{mM})$ resulted in significantly increased expression of caspase- 3 and caspase-9 genes when compared to the control ARPE-19 cells. Expression 
of caspase- 3 and caspase- 9 was significantly decreased in ARPE-19 cells pre-treated with

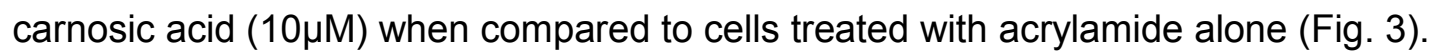

\subsection{Carnosic acid suppressed acrylamide-induced reactive oxygen species (ROS) production}

We investigated whether acrylamide treatment can increase intracellular ROS in ARPE-19 cells. As shown in Fig. 4, cells treated with $0.7 \mathrm{mM}$ and $1 \mathrm{mM}$ acrylamide exhibited notably increased ROS by $32.02 \%$ and $34.83 \%$ respectively compared with untreated control cells. Cells pre-treated with carnosic acid $(10 \mu \mathrm{M})$ then treated with acrylamide $(0.7$ and $1 \mathrm{mM})$ showed significantly reduced ROS by $15.02 \%$ and $17.33 \%$ respectively when compared with cells treated with acrylamide alone.

\subsection{Carnosic acid treatment reverses acrylamide-induced changes in the expression of} antioxidant genes

Acrylamide-induced ROS production is possibly due to cellular antioxidant imbalance, so we examined expression of antioxidant genes in ARPE-19 cells exposed to acrylamide. We found expression of antioxidant genes was decreased in acrylamide-treated cells compared to untreated cells (Fig. 5). Compared to the control group, expression of SOD1 gene was decreased by $50.24 \%$ following $0.7 \mathrm{mM}$ acrylamide treatment and by $56.58 \%$ following $1 \mathrm{mM}$ acrylamide treatment; GPX1 gene expression was decreased by $29.47 \%$ and $37.66 \%$ respectively; CAT gene expression was decreased by $47.80 \%$ and $52.27 \%$ respectively; NQO-1 gene expression was decreased by $33.67 \%$ and $53.04 \%$ respectively (although in the former case the difference was not statistically significant); and GCLM gene expression was decreased by $27.34 \%$ and $36.31 \%$ respectively (although in both cases the difference was not statistically significant). ARPE-19 cells pre-treated with carnosic acid $(10 \mu \mathrm{M})$ showed notably increased expression of these genes compared to cells treated with acrylamide alone: SOD1 expression was increased by $542.6 \%$ (pre-treatment with carnosic acid followed by treatment with acrylamide $(0.7 \mathrm{mM})$ ) and $577.84 \%$ (pre-treatment with carnosic 
acid followed by treatment with acrylamide (1.0mM)); GPX1 expression was increased by $384.2 \%$ and $304.13 \%$ respectively; CAT expression was increased by $457.66 \%$ and $418.39 \%$ respectively; NQO-1 expression was increased by $352.93 \%$ and $429.3 \%$ respectively; and GCLM expression was increased by $343.1 \%$ and $353.27 \%$ respectively (Fig.5).

We also investigated the effects of carnosic acid on SOD and CAT activities. As shown in Fig. 6, ARPE-19 cells treated with acrylamide at 0.7 or $1.0 \mathrm{mM}$ had SOD activities that were significantly reduced by $60.75 \%$ and $82.26 \%$ respectively, and for CAT by $23.86 \%$ and $48.6 \%$ respectively, when compared to untreated control cells. Pre-treatment with carnosic acid at $10 \mu \mathrm{M}$ resulted in significantly increased activities of SOD by $512.1 \%$ following treatment with acrylamide $(0.7 \mathrm{mM})$ and by $665.35 \%$ following treatment with acrylamide (1.0mM) and increased activity of CAT by $33.68 \%$ and $19.49 \%$ respectively, when compared to cells treated with acrylamide alone (Fig. $6 \mathrm{~A}$ and $\mathrm{B}$ ).

\subsection{Carnosic acid treatment reverses acrylamide-induced changes in the production of} glutathione and malondialdehyde

Acrylamide treatment can cause decreased glutathione (GSH) and increased malondialdehyde (MDA) in cell lines and in animal models (Kahkeshani et al., 2015). We investigated the levels of GSH and MDA in acrylamide-treated ARPE-19 cells and found that GSH was significantly decreased by $37.39 \%(0.7 \mathrm{mM}$ acrylamide treatment) and $65.02 \%$ ( $1 \mathrm{mM}$ acrylamide treatment) compared to the untreated cells. ARPE-19 cells pre-treated with carnosic acid $(10 \mu \mathrm{M})$ had significantly increased $\mathrm{GSH}$ by $247.24 \%(0.7 \mathrm{mM}$ acrylamide treatment) and $261.26 \%$ (1.0 mM acrylamide treatment), when compared to cells treated solely with acrylamide (Fig. 6C).

Production of MDA in ARPE-19 cells treated with acrylamide at 0.7 or $1.0 \mathrm{mM}$ was increased by $22.8 \%$ and $27.42 \%$ respectively, when compared to the untreated control cells. Pretreatment with carnosic acid $(10 \mu \mathrm{M})$ led to decreased levels of MDA by $14.99 \%(0.7 \mathrm{mM}$ acrylamide treatment) and $17.22 \%$ (1.0mM acrylamide treatment) when compared to cells treated with acrylamide alone (Fig. 6D). 


\subsection{Carnosic acid reverses acrylamide-induced changes in the expression of NRF2} gene

NRF2 is known to play an important role in protection against oxidative stress by enhancing the expression of antioxidant enzyme genes (Kobayashi and Yamamoto, 2006). Knockdown of NRF2 in PC12 cells further decreased the generation of GSH and increased MDA production induced by acrylamide (Pan et al., 2016). Firstly we examined expression of NRF2 gene by qRT-PCR (Fig. 7A) and found acrylamide exposure (0.7 or $1 \mathrm{mM})$ caused significantly decreased expression of NRF2 by $45.50 \%$ and $51.43 \%$ respectively, when compared to the untreated control cells. However, pre-treatment with carnosic acid $(10 \mu \mathrm{M})$ induced a significant increase in NRF2 expression by $432.65 \%(0.7 \mathrm{mM}$ acrylamide treatment) and $433.18 \%$ (1.0mM acrylamide treatment), when compared to cells treated solely with acrylamide (Fig. 7B). Secondly we examined NRF2 protein level by western blotting using anti-NRF2 antibody (Fig. 7C) and found the level of NRF2 protein was significantly decreased by $65.15 \%$ and $82.68 \%$ in ARPE-19 cells treated with acrylamide at 0.7 and $1.0 \mathrm{mM}$ respectively, when compared to untreated control cells. ARPE-19 cells, pretreated with carnosic acid $(10 \mu \mathrm{M})$ and then treated with acrylamide $(0.7$ or $1.0 \mathrm{mM})$, had a significant increase in NRF2 protein by $423.33 \%$ and $629.21 \%$ respectively, compared to cells treated solely with acrylamide (Fig. 7D).

\section{Discussion}

Humans can be chronically exposed to acrylamide through the intake of certain foods (such as bread, cereals, potato chips and crisps, and coffee) cooked or heated at high temperatures. Workers exposed occupationally to acrylamide exhibited peripheral and central neuropathies (Pennisi et al., 2013). Tunnel workers exposed to Nmethylolacrylamide and acrylamide experienced decreased light sensitivity and colour discrimination (Goffeng et al., 2008a). Electroretinographic assessment of these workers showed that cone photoreceptor function was significantly affected (Goffeng et al., 2008b). Adult rodents and primates exposed to acrylamide showed visual function defects (Merigan 
et al., 1985; Ali et al., 2014). Following maternal exposure to acrylamide or acrylamidecontaining fried potato chips, rat offspring showed morphologically abnormal retinal pigment epithelium (RPE) cells, photoreceptors and ganglion cells (El-Sayyad et al., 2011; Sakr et al., 2011). However, information about acrylamide-induced toxicity in RPE cells and the effects of carnosic acid on acrylamide-induced toxicity is very limited.

Our current study used ARPE-19 cells as an in vitro model to assess the toxicity of acrylamide and evaluate the protective effects of 24 hours of pre-treatment with carnosic acid. Dietary polyphenols can undergo degradation in cell culture conditions (Xiao and Högger, 2014) but carnosic acid in ethanolic solutions is fairly stable, degrading by less than 20\% after 24 hours (Zhang et al., 2012). Previous studies have shown that acrylamide exposure caused significantly decreased cell viability and increased ROS production in neurally-associated cell lines such as PC12, SH-SY5Y, U-1240 MG, U-87 MG and U-251 MG cells (Chen et al., 2009; Chen et al., 2013; Lee et al., 2014; Mehri et al., 2012; Pan et al., 2016; Sumizawa and Igisu, 2007). Acrylamide also inhibited the differentiation and proliferation of SH-SY5Y and U-1240 MG cells (Chen and Chou, 2015) and promoted endothelial cell (HUVEC) ageing (Sellier et al., 2015). Our results also demonstrated that acrylamide exposure resulted in dose-dependent decreased cell viability (Fig. 1A) and increased ROS production (Fig. 4). Acrylamide-induced cell death was thought to be caspase-3 dependent; elevated caspase-3 activities have been reported in acrylamideexposed SH-SY5Y, PC12 and Caco-2 cells (Pan et al., 2016; Rodríguez-Ramiro et al., 2011; Sumizawa and Igisu, 2007), A recent study showed that acrylamide-induced cell death was mediated by ER stress and associated elF2 $\alpha-A T F 4-C H O P$ signalling pathway (Komoike \& Matsuoka, 2016). Our data showed that acrylamide exposure caused marked cell death in RPE cells, possibly through the caspase-3 dependent pathway (Figs. 2 and 3) although we cannot exclude the involvement of other cell death pathways in acrylamide-treated RPE cells.

Increased ROS production in acrylamide-exposed cells is due to the disruption of redox homeostasis. Acrylamide exposure resulted in significantly decreased GSH level and 
antioxidant enzyme activities in in vitro mammalian cells and in in vivo animal models (Ali et al., 2014; Kahkeshani et al., 2015; Lakshmi et al., 2012; Mehri et al., 2015; Pan et al., 2016; Rodríguez-Ramiro et al., 2011). MDA, a marker for lipid peroxidation and oxidative stress, was also overproduced in acrylamide-exposed cells and animals (Ali et al, 2014; Mehri et al, 2015; Pan et al, 2016). We too found that RPE cells exposed to acrylamide had notably decreased GSH and antioxidant enzyme (SOD and catalase) activities, and MDA was also significantly increased (Fig. 6), suggesting acrylamide treatment caused the redox imbalance in RPE cells.

Carnosic acid has shown a protective role in cancer, vascular diseases, neurodegenerative diseases, metabolic disorders and organ injuries (Bahri et al., 2016). Carnosic acid protected retinal cells from $\mathrm{H}_{2} \mathrm{O}_{2}$-induced oxidative damage in vitro and from light-induced retinal degeneration in vivo (Rezaie et al., 2012); Administration of carnosic acid in rd10 mouse model of retinitis pigmentosa suppressed photoreceptor degeneration (Kang et al., 2016). NRF2 has been involved in carnosic acid-mediated neuroprotection (Kang et al., 2016; Rezaie et al., 2012; Satoh et al., 2008). Carnosic acid treatment resulted in NRF2 upregulation in cortical neurons, retinal cells and tissues (Kang et al., 2016; Rezaie et al., 2012; Satoh et al., 2008). NRF2 signal pathway also mediated acrylamide-induced apoptosis in PC12 cells (Pan et al., 2016). Our results demonstrated that acrylamide exposure downregulated NRF2 expression in RPE cells and that carnosic acid treatment carnosic acid treatment was able to reverse these effects.

In summary, our results suggest that carnosic acid can protect RPE cells from acrylamide-induced oxidative damages through NRF2 signalling pathway and has a potential for neuroprotection against acrylamide-induced retinal toxicity in humans. 


\section{Acknowledgement}

AA and RHA are suported by PhD scholarships from Saudi Arabia Government. We would like to thank the Rosetrees Trust, the Glasgow Children's Hospital Charity and the Visual Research Trust for supporting this work.

\section{References}

Ali, M.A., Aly, E.M., Elawady, A.I., 2014. Effectiveness of selenium on acrylamide toxicity to retina. Int. J. Ophthalmol. 7(4), 614-620.

Aruoma, O., Halliwell, B., Aeschbach, R., Löligers, J., 1992. Antioxidant and pro-oxidant properties of active rosemary constituents: carnosol and carnosic acid. Xenobiotica. 22(2), 257-268.

Bahri, S., Jameleddine, S., Shlyonsky, V., 2016. Relevance of carnosic acid to the treatment of several health disorders: Molecular targets and mechanisms. Biomed. Pharmacother. 84, $569-582$.

Boon, P.E., de Mul, A., van der Voet, H., van Donkersgoed, G., Brette, M., van Klaveren, J.D., 2005. Calculations of dietary exposure to acrylamide. Mutat. Res. Toxicol. Environ. Mutagen 580, $143 e 155$.

Becalski, A., Lau, B.P., Lewis, D., Seaman, S.W., 2003. Acrylamide in foods: occurrence, sources, and modeling. J. Agric. Food Chem., 51(3), 802-808.

Chen, J.H., Wu, K.Y., Chiu, IM., Tsou, T.C., Chou, C.C., 2009. Acrylamide-induced astrogliotic and apoptotic responses in human astrocytoma cells. Toxicol. In Vitro 23(5), 855861.

Chen, J.H., Yang, C.H., Wang, Y.S., Lee, J.G., Cheng, C.H., Chou, C.C., 2013. Acrylamideinduced mitochondria collapse and apoptosis in human astrocytoma cells. Food Chem. Toxicol. 51, 446-452.

Chen, J.H., Chou, C.C., 2015. Acrylamide inhibits cellular differentiation of human neuroblastoma and glioblastoma cells. Food Chem. Toxicol. 82, 27-35. 
Cortese, K., Daga, A., Monticone, M., Tavella, S., Stefanelli, A., Aiello, C., Bisio, A., Bellese, G., Castagnola, P., 2016. Carnosic acid induces proteasomal degradation of Cyclin B1, RB and SOX2 along with cell growth arrest and apoptosis in GBM cells. Phytomedicine 23(7), 679-685.

Dobrovolsky, V.N., Pacheco-Martinez, M.M., McDaniel, L.P., Pearce, M.G., Ding, W., 2016. In vivo genotoxicity assessment of acrylamide and glycidyl methacrylate. Food Chem. Toxicol. 87, 120-127.

Doerge, D.R., Young, J.F., Chen, J.J., DiNovi, M.J., Henry, S.H., 2008. Using dietary exposure and physiologically based pharmacokinetic/pharmacodynamic modeling in human risk extrapolations for acrylamide toxicity. J. Agric. Food Chem. 56, 6031-6038.

Dybing, E., Farmer, P.B., Andersen, M., Fennell, T.R., Lalljie, S.P., Müller, D.J., Olin, S., Petersen, B.J., Schlatter, J., Scholz, G., Scimeca, J.A., Slimani, N., Törnqvist, M., Tuijtelaars, S., Verger, P., 2005. Human exposure and internal dose assessments of acrylamide in food. Food Chem. Toxicol. 43(3), 365-410.

EFSA, 2015. Scientific opinion on acrylamide in food. EFSA J. 13, 4104.

El-Sayyad, H.I., Sakr, S.A., Badawy, G.M., Afify, H.S., 2011. Hazardous effects of fried potato chips on the development of retina in albino rats. Asian Pac. J. Trop. Biomed. 1(4), 253-260.

El-Tantavi, H.G.M., 2007. The protective role of ginger (Zingiber officinale) against acrylamide induced neurotoxicity in mice. Egypt. J. Histol. 30, 325-336

Eskin, T.A., Lapham, L.W., Maurissen, J.P., Merigan, W.H., 1985. Acrylamide effects on the macaque visual system. II. Retinogeniculate morphology. Invest. Ophthalmol. Vis. Sci. 26(3), 317-329.

Eskin, T.A., Merigan, W.H., 1986. Selective acrylamide-induced degeneration of color opponent ganglion cells in macaques. Brain Res. 378(2), 379-384.

Exon, J. H., 2006. A review of the toxicology of acrylamide. J Toxicol Environ Health B Crit Rev. 9(5), 397-412. 
Goffeng, L.O., Heier, M.S., Kjuus, H., Sjöholm, H., Sørensen, K.A., Skaug, V., 2008a. Nerve conduction, visual evoked responses and electroretinography in tunnel workers previously exposed to acrylamide and $\mathrm{N}$-methylolacrylamide containing grouting agents. Neurotoxicol Teratol. 30(3),186-194.

Goffeng, L.O., Kjuus, H., Heier, M.S., Alvestrand, M., Ulvestad, B., Skaug, V., 2008b. Colour vision and light sensitivity in tunnel workers previously exposed to acrylamide and $\mathrm{N}$ methylolacrylamide containing grouting agents. Neurotoxicology 29(1), 31-39.

Haraguchi, H., Saito, T., Okamura, N., Yagi, A., 1995. Inhibition of lipid peroxidation and superoxide generation by diterpenoids from Rosmarinus officinalis. Planta Med. 61(4), 333336.

Jakobsen, L.S., Granby, K., Knudsen, V.K., Nauta, M., Pires, S.M., Poulsen, M., 2016. Burden of disease of dietary exposure to acrylamide in Denmark. Food Chem. Toxicol. 90, $151-159$

Kahkeshani, N., Saeidnia, S., Abdollahi, M., 2015. Role of antioxidants and phytochemicals on acrylamide mitigation from food and reducing its toxicity. J. Food Sci. Technol. 52(6), 3169-3186.

Kang, K., Tarchick, M.J., Yu, X., Beight, C., Bu, P., Yu, M., 2016. Carnosic acid slows photoreceptor degeneration in the Pde6b(rd10) mouse model of retinitis pigmentosa. Sci. Rep. 6, 22632.

Kobayashi, M., \& Yamamoto, M., 2006. Nrf2-Keap1 regulation of cellular defense mechanisms against electrophiles and reactive oxygen species. Adv. Enzyme Regul. 46,113140.

Komoike, Y., Matsuoka, M., 2016. Endoplasmic reticulum stress-mediated neuronal apoptosis by acrylamide exposure. Toxicol. Appl. Pharmacol. 310, 68-77. Konings, E.J.M., Baars, A.J., Van Klaveren, J.D., Spanjer, M.C., Rensen, P.M., Hiemstra, M., Van Kooij, J.A., Peters, P.W.J., 2003. Acrylamide exposure from foods of the Dutch population and an assessment of the consequent risks. Food Chem. Toxicol. 41, 1569-1579. 
Kuperman, A.S., 1958. Effects of acrylamide on the central nervous system of the cat. J.

446

447

448

449

450

451

452

453

454

455

456

457

458

459

460

461

462

463

464

465

466

467

468

469

470

Pharmacol. Exp. Ther. 123, 180-192.

Lakshmi, D., Gopinath, K., Jayanthy, G., Anjum, S., Prakash, D., Sudhandiran, G., 2012.

Ameliorating effect of fish oil on acrylamide induced oxidative stress and

neuronal apoptosis in cerebral cortex. Neurochem. Res. 37(9), 1859-1867.

Lee, J.G., Wang, Y.S., Chou, C.C., 2014. Acrylamide-induced apoptosis in rat primary astrocytes and human astrocytoma cell lines. Toxicol. In Vitro 28(4), 562-570.

Lin, C.Y., Chen, J.H., Fu, R.H., Tsai, C.W., 2014. Induction of Pi form of glutathione Stransferase by carnosic acid is mediated through PI3K/Akt/NF-KB pathway and protects against neurotoxicity. Chem. Res. Toxicol. 27(11), 1958-1966.

Livak, K.J., Schmittgen, T.D., 2001. Analysis of relative gene expression data using real-time quantitative PCR and the 2(-Delta Delta C(T)) Method. Methods 25(4), 402-408.

Lopachin, R.M., Decaprio, A.P., 2005. Protein adduct formation as a molecular mechanism in neurotoxicity. Toxicol. Sci. 86(2), 214-225.

Mehri, S., Abnous, K., Khooei, A., Mousavi, S.H., Shariaty, V.M., Hosseinzadeh, H., 2015.

Crocin reduced acrylamide-induced neurotoxicity in Wistar rat through inhibition of oxidative stress. Iran J. Basic Med. Sci. 18(9), 902-908.

Mehri, S., Abnous, K., Mousavi, S.H., Shariaty, V.M., Hosseinzadeh, H., 2012.

Neuroprotective effect of crocin on acrylamide-induced cytotoxicity in PC12 cells. Cell Mol. Neurobiol. 32(2), 227-235.

Mei, N., Hu, J., Churchwell, M.I., Guo, L., Moore, M.M., Doerge, D.R., Chen, T., 2008.

Genotoxic effects of acrylamide and glycidamide in mouse lymphoma cells. Food Chem.

Toxicol. 46, 628-636.

Mei, N., McDaniel, L.P., Dobrovolsky, V.N., Guo, X., Shaddock, J.G., Mittelstaedt, R.A., Azuma, M., Shelton, S.D., McGarrity, L.J., Doerge, D.R., Heflich, R.H., 2010. The genotoxicity of acrylamide and glycidamide in big blue rats. Toxicol. Sci. 115, 412-421. 
Merigan, W.H., Barkdoll, E., Maurissen, J.P., Eskin, T.A., Lapham, L.W., 1985.

Acrylamide effects on the macaque visual system. I. Psychophysics and electrophysiology. Invest. Ophthalmol. Vis. Sci. 26(3), 309-316.

Pan, X., Yan, D., Wang, D., Wu, X., Zhao, W., Lu, Q., Yan, H., 2016. Mitochondrionmediated apoptosis induced by acrylamide is regulated by a balance between Nrf2 antioxidant and MAPK signaling pathways in PC12 cells. Mol Neurobiol, [Epub ahead of print].

Patnaik, S.R., Raghupathy, R.K., Zhang, X., Mansfield, D., Shu, X., 2015. The role of RPGR and its interacting proteins in ciliopathies. J. Ophthalmol. 2015, 414781.

Parzefall, W., 2008. Minireview on the toxicity of dietary acrylamide. Food Chem. Toxicol. 46(4), 1360-1364.

Poeckel, D., Greiner, C., Verhoff, M., Rau, O., Tausch, L., Hörnig, C., Steinhilber, D., Schubert-Zsilavecz, M., Werz, O., 2008.. Carnosic acid and carnosol potently inhibit human 5-lipoxygenase and suppress pro-inflammatory responses of stimulated human polymorphonuclear leukocytes. Biochem. Pharmacol., 76(1), 91-97.

Pennisi, M., Malaguarnera, G., Puglisi, V., Vinciguerra, L., Vacante, M., Malaguarnera, M., 2013. Neurotoxicity of acrylamide in exposed workers. Int. J. Environ. Res. Public Health 10, 3843-3854.

Rezaie, T., McKercher, S.R., Kosaka, K., Seki, M., Wheeler, L., Viswanath, V., Chun, T., Joshi, R., Valencia, M., Sasaki, S., Tozawa, T., Satoh, T., Lipton, S.A., 2012. Protective effect of carnosic acid, a pro-electrophilic compound, in models of oxidative stress and lightinduced retinal degeneration. Invest. Ophthalmol. Vis. Sci. 53(12), 7847-7854.

Rodríguez-Ramiro, I., Ramos, S., Bravo, L., Goya, L., Martín, M.Á., 2011. Procyanidin B2 and a cocoa polyphenolic extract inhibit acrylamide-induced apoptosis in human Caco-2 cells by preventing oxidative stress and activation of JNK pathway. J. Nutr. Biochem. 22(12):11861194. 
Russo, A., Lombardo, L., Troncoso, N., Garbarino, J., Cardile, V., 2009. Rosmarinus officinalis extract inhibits human melanoma cell growth. Nat. Prod. Commun. 4(12), 17071710.

Sakr, S.A., Badawy, G.M., El-sayyad, H.I., Afify, H.S., 2011. Adverse effects of acrylamide on the developing retina of albino rats. J. Basic Appl. Sci. Res. 1(7), 706-712.

Satoh, T., Kosaka, K., Itoh, K., Kobayashi, A., Yamamoto, M., Shimojo, Y., Kitajima, C., Cui, J., Kamins, J., Okamoto, S., Izumi, M., Shirasawa, T., Lipton, S.A., 2008. Carnosic acid, a catechol-type electrophilic compound, protects neurons both in vitro and in vivo through activation of the Keap1/Nrf2 pathway via S-alkylation of targeted cysteines on Keap1. J. Neurochem. 104(4), 1116-1131.

Sellier, C., Boulanger, E., Maladry, F., Tessier, F.J., Lorenzi, R., Nevière, R., Desreumaux, P., Beuscart, J.B., Puisieux, F., Grossin, N., 2015. Acrylamide induces accelerated endothelial aging in a human cell model. Food Chem. Toxicol. 83, 140-145.

Sozio, P., lannitelli, A., Cerasa, L.S., Cacciatore, I., Cornacchia, C., Giorgioni, G., Ricciutelli, M., Nasuti, C., Cantalamessa, F., Di Stefano, A., 2008. New L-dopa codrugs as potential antiparkinson agents. Arch Pharm. (Weinheim) 341(7), 412-417.

Strauss, O., 2005. The retinal pigment epithelium in visual function. Physiol. Rev. 85(3), 845881.

Sumizawa, T., Igisu, H., 2007. Apoptosis induced by acrylamide in SH-SY5Y cells. Arch Toxicol. 81(4), 279-282.

Tareke, E., Rydberg, P., Ericksson, S., Törnqvist, M., 2002. Analysis of acrylamide, a carcinogen formed in heated foodstuffs. J. Agric. Food Chem. 50, 4998-5006.

Vázquez, N.M., Fiorilli, G., Cáceres Guido, P.A., Moreno, S., 2016. Carnosic acid acts synergistically with gentamicin in killing methicillin-resistant Staphylococcus aureus clinical isolates. Phytomedicine 23(12),1337-1343.

Wu, C.R., Tsai, C.W., Chang, S.W., Lin, C.Y., Huang, L.C., Tsai, C.W.. 2015. Carnosic acid protects against 6-hydroxydopamine-induced neurotoxicity in in vivo and in vitro model of 
524 Parkinson's disease: involvement of antioxidative enzymes induction. Chem. Biol. Interact.

$525225,40-46$.

526 Xiao, J., Högger, P., 2015. Stability of dietary polyphenols under the cell culture conditions:

527 avoiding erroneous conclusions. J. Agric. Food Chem. 63(5),1547-1557.

528 Zhang, Y., Smuts, J.P., Dodbiba, E., Rangarajan, R., Lang, J.C., Armstrong, D.W., 2012.

529 Degradation study of carnosic acid, carnosol, rosmarinic acid, and rosemary extract

530 (Rosmarinus officinalis L.) assessed using HPLC. J. Agric. Food Chem., 60(36), 9305-9314.

531 Zyzak, D.V., Sanders, R.A., Stojanovic, M., Tallmadge, D.H., Eberhart, B.L., Ewald, D.K.,

532 Gruber, D.C., Morsch, T.R., Strothers, M.A., Rizzi, G.P., Villagran, M.D., 2003.

533 Acrylamide formation mechanism in heated foods. J. Agric. Food Chem. 51(16), 4782-4787.

534

535

536

537

538

539

540

541

542

543

544

545

546

547

548

549

550

551 
552 Table 1 The primers used for qRT-PCR

\begin{tabular}{|l|l|l|l|l|l|}
\hline Gene & Forward primers 5'-3' & Reverse primers 5'-3 & $\begin{array}{l}\text { Annealing } \\
\text { temperature }{ }^{\circ} \mathrm{C}\end{array}$ & PCR product & Reference \\
\hline NRF2 & AGTGGATCTGCCAACTACTC & CATCTACAAACGGGAATGTCTG & 56.5 & 106 & 2006) \\
\hline GPX 1 & AGTCCACCGTGTATGCCTTC & CTCCTGGTGTCCGAACTGAT & 57.0 & 218 & Designed in lab \\
\hline SOD 1 & AGGGCATCATCAATTTCGAG & CATTGCCCAAGTCTCCAAC & 55.0 & 217 & Designed in lab \\
\hline CAT & ATCTCGTTGGAAATAACACC & AGAAACCTGATGCAGAGACT & 57.5 & 161 & Designed in lab \\
\hline NQO-1 & CCTCTATGCCATGAACTT & TATAAGCCAGAACAGACTC & 48.6 & 107 & Qaisiya et al,2013 \\
\hline GCLM & GCCATAGGTACCTCTGATC & CTTGACAGACAACATACTGTC & 51.2 & 487 & Rezaie et al,2012 \\
\hline CASPASE 3 & AACTGGACTGTGGCATTG & ACCAGGTGCTGTGGAGTA & 54.3 & 107 & Zhou et al., 2008 \\
\hline CASPASE 9 & ATGGACGAAGCGGATCGGCGGCTCC & GCACCACTGGGGTAAGGTTTTCTAG & 64 & 331 & Ceruti et al., 2005 \\
\hline B-ACTIN & TCCACGAAACTACCTTCAACTC & GTCATACTCCTGCTTGCTGAT & 57.5 & Designed in lab \\
\hline
\end{tabular}

553

554

555

556

557

558

559

560

561

562

563

564

565

566

567

568

569

570 


\section{Figure legends}

572 Figure 1 The effects of acrylamide (ACR) and carnosic acid (CA) on cell viability. (A) Dose-

573

574

575

576

577

578

579

580

581

582

583

584

585

586

587

588

589

590

591

592

593

594

595

596

597 dependent decreases in cell viability in ARPE-19 cells treated with ACR at different concentrations. (B) Dose-dependent decreases in cell viability in ARPE-19 cells treated with CA at different concentrations. (C) Microscopic images of ARPE-19 cells exposed to ACR and / or CA. (D) CA pre-treatment in ARPE-19 cells reversed ACR-caused toxic effects. All data are presented as the means \pm standard error of three independent experiments.

Statistical significance was analysed using on-way ANOVA test. UT, untreated control cells; ns, no significance; ${ }^{* *} \mathrm{P}<0.01,{ }^{* * *} \mathrm{P}<0.001,{ }^{* * *} \mathrm{P}<0.0001$. (E) Structure of acrylamide and carnosic acid.

Figure 2 Significant increases of apoptosis in ACR-exposed ARPE-19 cells detected by a TUNEL assay. (A) Nuclei of apoptotic cells were stained in green. Cells treated with DNase were used as positive control for apoptosis. ARPE-19 cells were exposed to 0.7 or $1 \mathrm{mM}$ of ACR only, or $0.7 \mathrm{mM} \mathrm{ACR}+10 \mu \mathrm{M} \mathrm{CA}$, or $1 \mathrm{mM} \mathrm{ACR}+10 \mu \mathrm{M}$ CA for 24 hours then stained with TUNEL reagents and DAPI to detect apoptotic cells. (B) Quantification of apoptotic cell number in 300 cells (in percentage). All data are presented as the means \pm standard error of three independent experiments. Statistical significance of apoptotic cells between each group was analysed using one-way ANOVA test. ${ }^{* *} \mathrm{P}<0.01,{ }^{* * *} \mathrm{P}<0.001,{ }^{* * *} \mathrm{P}<0.0001$.

Figure 3 ACR exposure led to notably increased expression of caspase 3 and 9, pretreatement with CA reversed the effects. (A) Agarose gel electrophoresis of qRT-PCR products. (B) Expression levels of caspase 3 in ARPE-19 cells treated with ACR only for $24 \mathrm{~h}$ or pre-treated with CA then treated with ACR for $24 \mathrm{~h}$ were measured by qRT-PCR. (C) Expression levels of caspase 9 in ARPE-19 cells treated with ACR only for $24 \mathrm{~h}$ or pretreated with $\mathrm{CA}$ then treated with $\mathrm{ACR}$ for $24 \mathrm{~h}$ were measured by qRT-PCR. All data are presented as the means \pm standard error of three independent experiments. Statistical significance of 
expression of caspase 3 and 9 was analysed using one-way ANOVA test. UT, untreated control cells; ns, no significance; ${ }^{*} \mathrm{P}>0.05,{ }^{* *} \mathrm{P}<0.01,{ }^{* * *} \mathrm{P}<0.001,{ }^{* * *} \mathrm{P}<0.0001$.

Figure 4 Pre-treatment with CA suppressed ACR-induced ROS production. ARPE-19 cells were exposed to ACR only or pre-treated with CA then treated with ACR. ROS production was measured using DCFH-DA staining. All data are presented as the means \pm standard error of three independent experiments. Statistical significance was analysed using on way ANOVA test. UT, untreated control cells; ${ }^{* *} \mathrm{P}<0.001,{ }^{* * * *} \mathrm{P}<0.0001$.

Figure 5 ACR exposure led to notably decreased expression of antioxidant genes and pretreatment with CA reversed the effects. (A) Agarose gel electrophoresis of qRT-PCR products. Expression levels of SOD1 (B), GPX1 (C), catalase (D), NQO-1 (E) and GCLM in ARPE-19 cells treated with ACR only for $24 \mathrm{~h}$, or pre-treated with CA then treated with ACR for $24 \mathrm{~h}$, were measured by qRT-PCR. All data are presented as the means \pm standard error of three independent experiments. Statistical significance of expression of these anti-oxidant genes was analysed using one way ANOVA test UT, untreated control cells; ns, no significance; ${ }^{*} \mathrm{P}<0.05,{ }^{* *} \mathrm{P}<0.01,{ }^{* * *} \mathrm{P}<0.001,{ }^{* * * *} \mathrm{P}<0.0001$.

Figure 6 CA treatment reversed ACR-induced effects on the activities of SOD and catalase, the level of GSH and MDA. Activities of SOD (A) and catalase (B) were significantly decreased in ARPE-19 cells challenged with ACR only for $24 \mathrm{~h}$, and notably increased when pre-treated with CA. (C) The generation of GSH was significantly decreased in ARPE-19 cells challenged with ACR only for $24 \mathrm{~h}$, and notably increased when pre-treated with CA. (D) MDA production was significantly increased in ARPE-19 cells challenged with ACR only for $24 \mathrm{~h}$, and notably decreased when pre-treated with CA. All data are presented as the means \pm standard error of three independent experiments. Statistical significance was analysed using one-way ANOVA test. UT, untreated control cells. ${ }^{*} P<0.05$, ${ }^{* *} \mathrm{P}<0.001$, $\left.{ }^{* * *} \mathrm{P}<0.001,{ }^{* * * *} \mathrm{P}<0.0001\right)$. 
626 Figure 7 ACR exposure downregulated the expression of NRF2 and pre-treatment with CA 627 reversed the effects. (A) Agarose gel electrophoresis of qRT-PCR products. (B) Expression 628 levels of NRF2 in ARPE-19 cells treated with ACR only for $24 \mathrm{~h}$ or pre-treated with CA then 629 treated with ACR for $24 \mathrm{~h}$ were measured by qRT-PCR. (C) Protein levels of NRF2 in ARPE63019 cells treated with ACR only for $24 \mathrm{~h}$ or pre-treated with CA then treated with ACR for $24 \mathrm{~h}$ were examined by western blotting. (D) Quantification of NRF2 protein levels normalized with

632 GAPDH protein. All data are presented as the means \pm standard error of three independent 633 experiments. Statistical significance was analysed using one-way ANOVA test. UT, untreated 634 control cells; ${ }^{*} \mathrm{P}<0.05,{ }^{* *} \mathrm{P}<0.01,{ }^{* * *} \mathrm{P}<0.001,{ }^{* * * *} \mathrm{P}<0.0001$.

635

636

637

638

639

640

641

642

643

644

645

646

647

648

649

650

651

652

653 

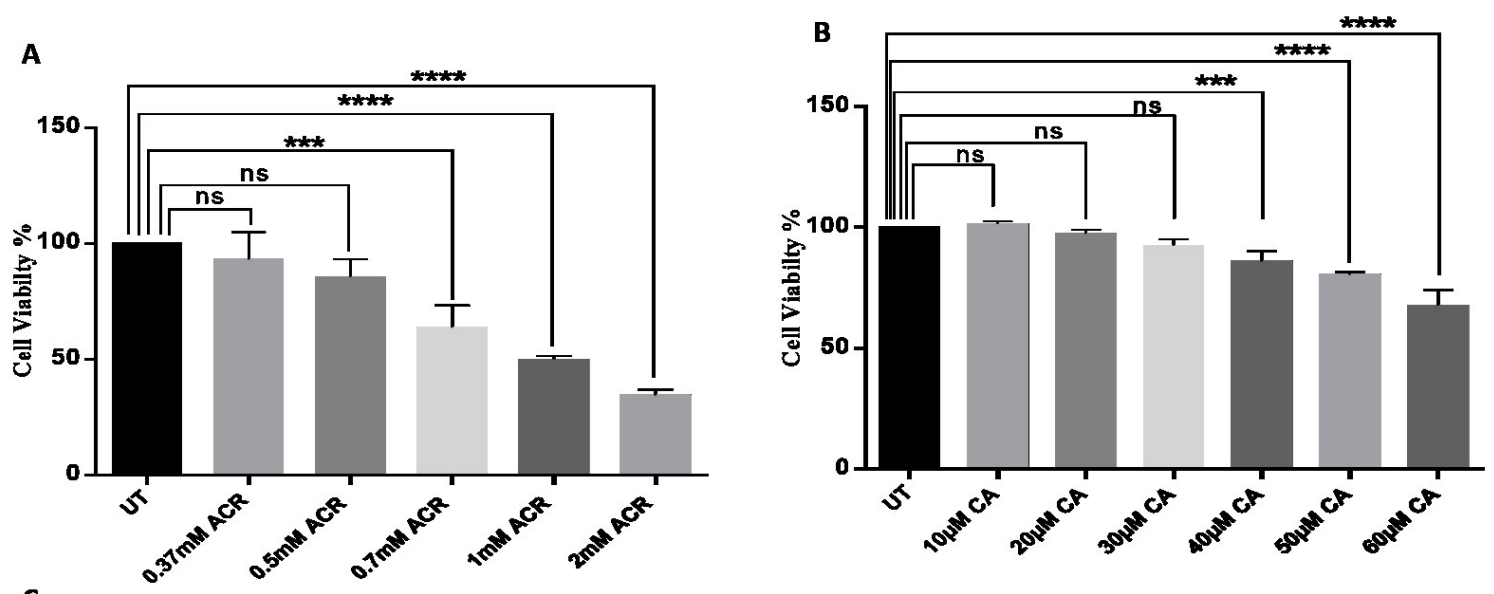

C
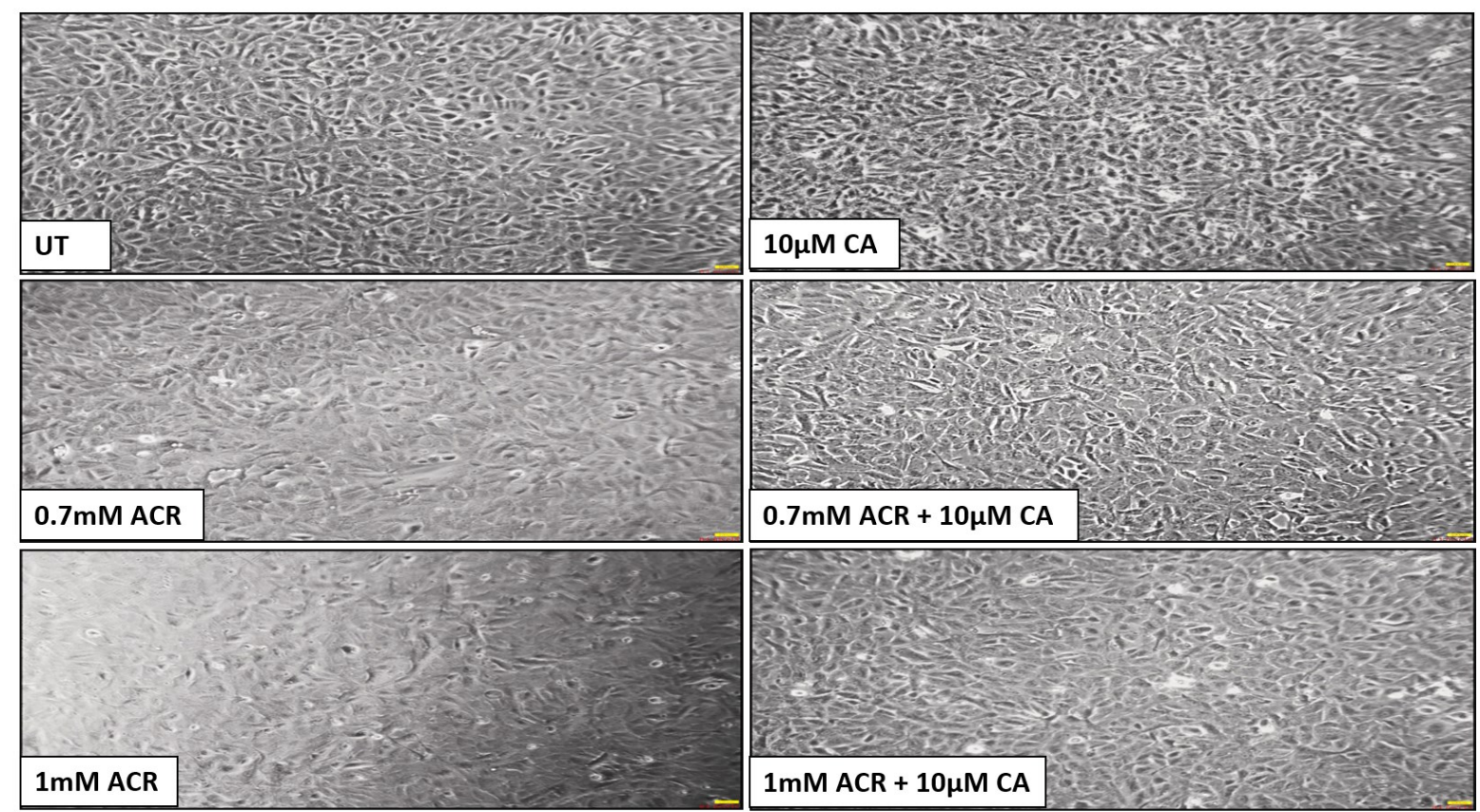

D

E
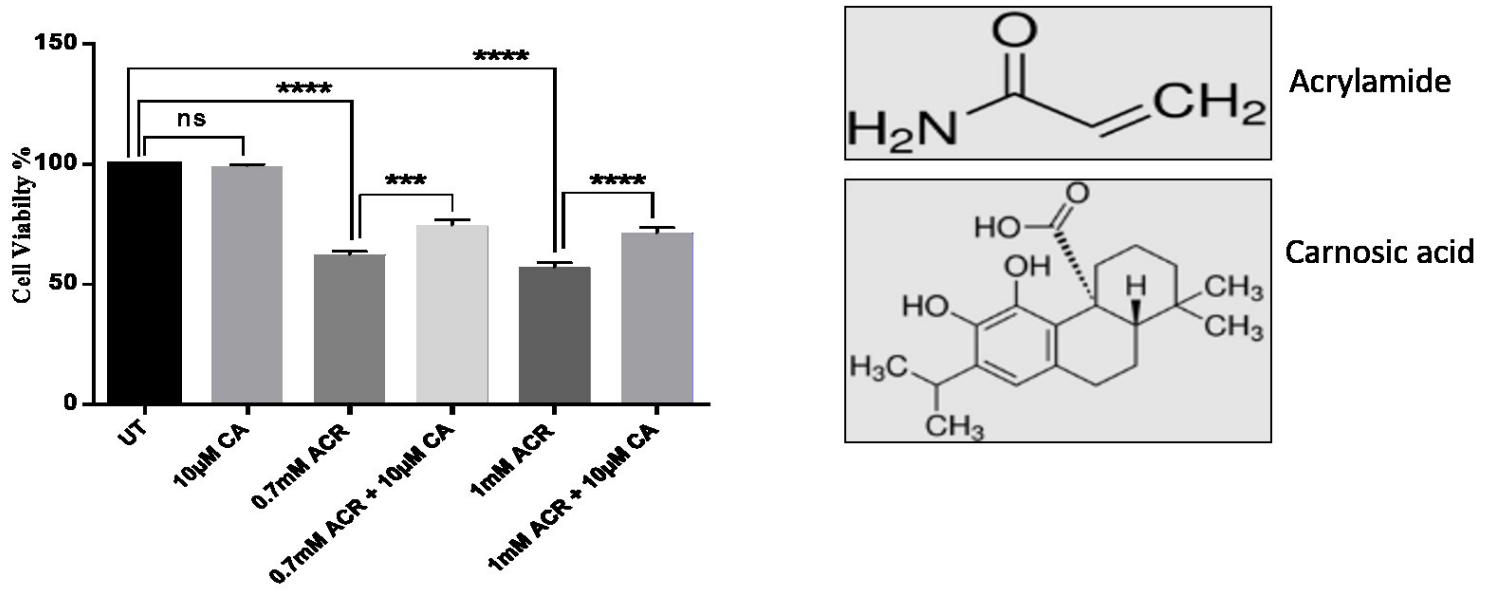
Figure 2
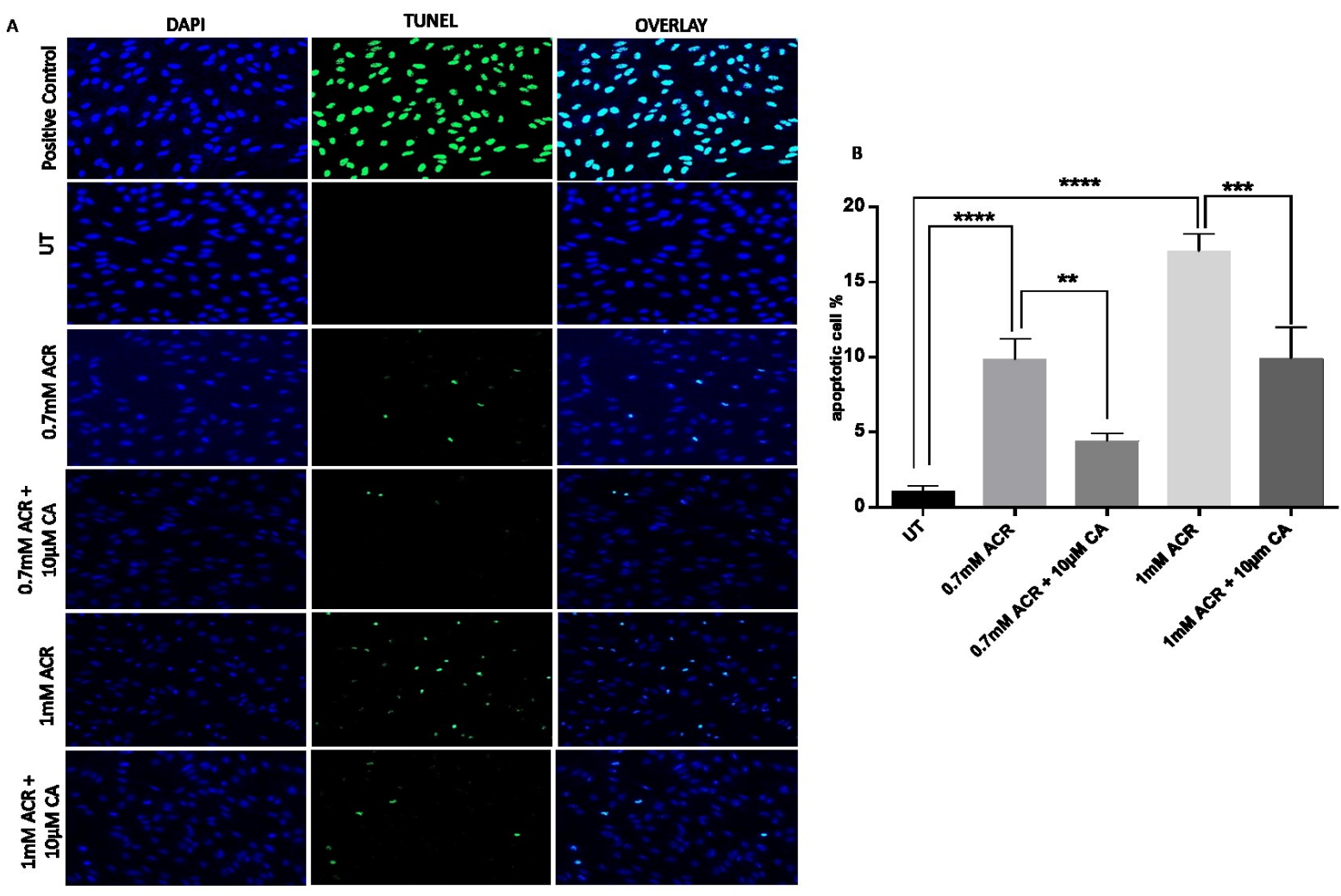

658

659

660

661

662

663

664

665

666

667

668

669

670

671 
Figure 3

A

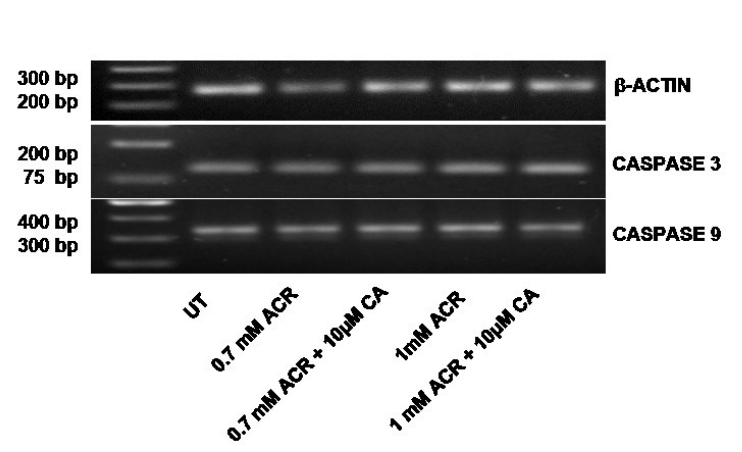

c

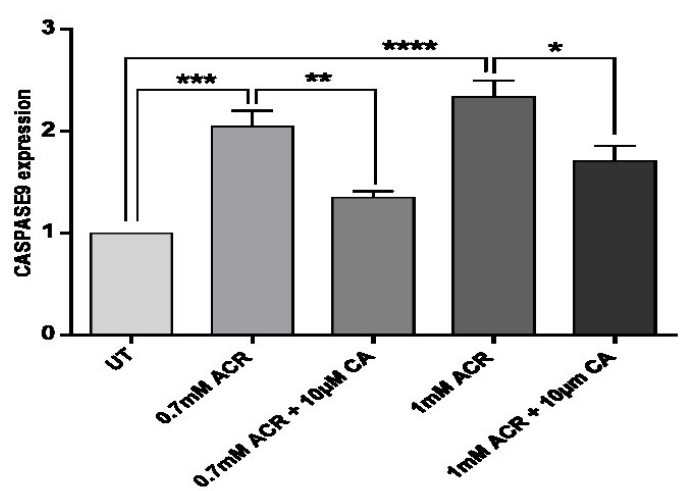

B

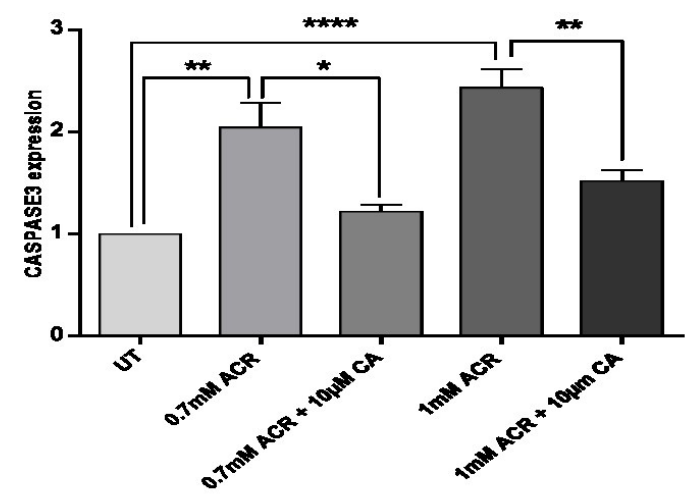

673

674

675

676

677

678

679

680

681

682

683

684

685

686 
Figure 4

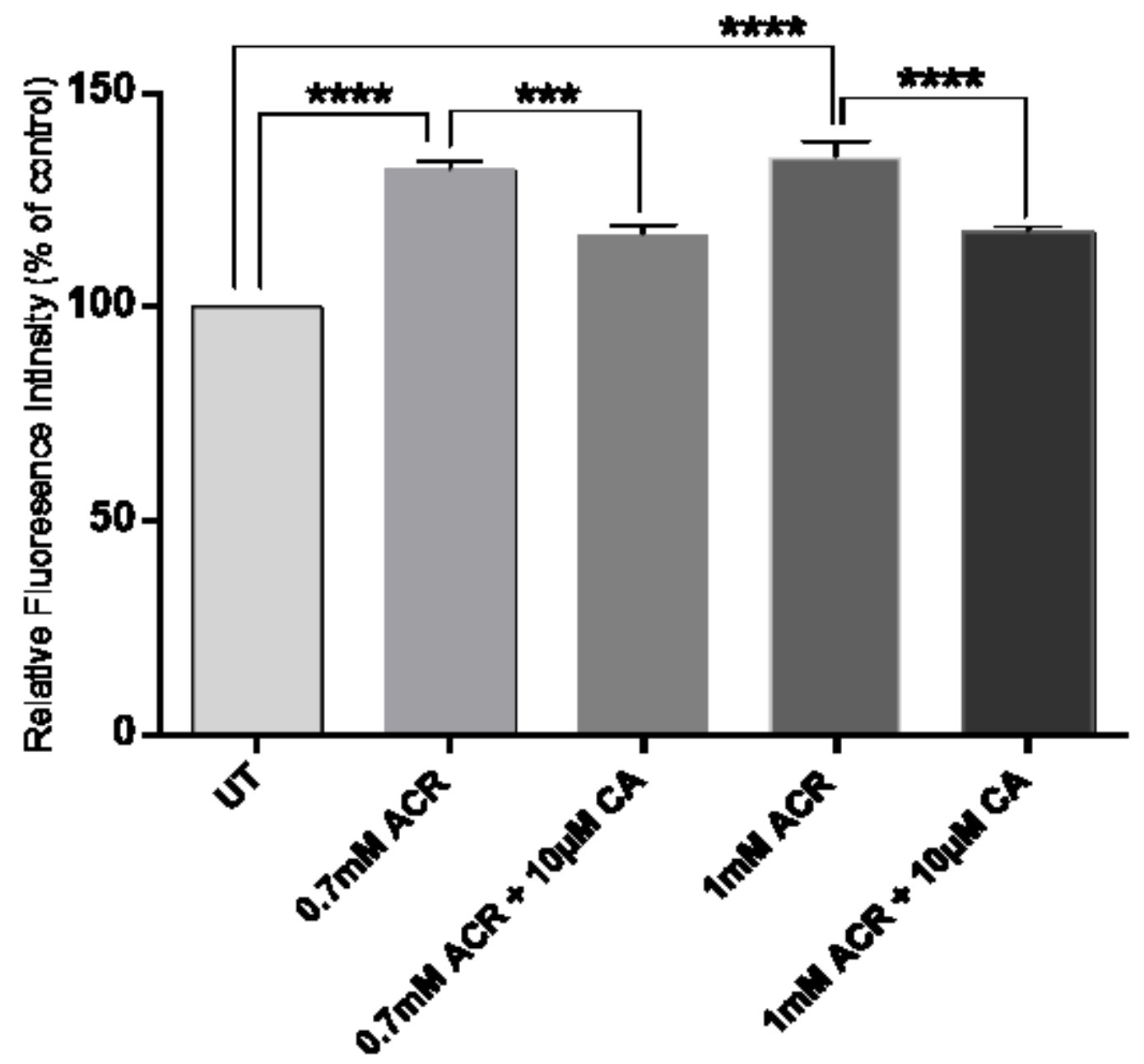

688

689

690

691

692

693

694

695

696

697

698 

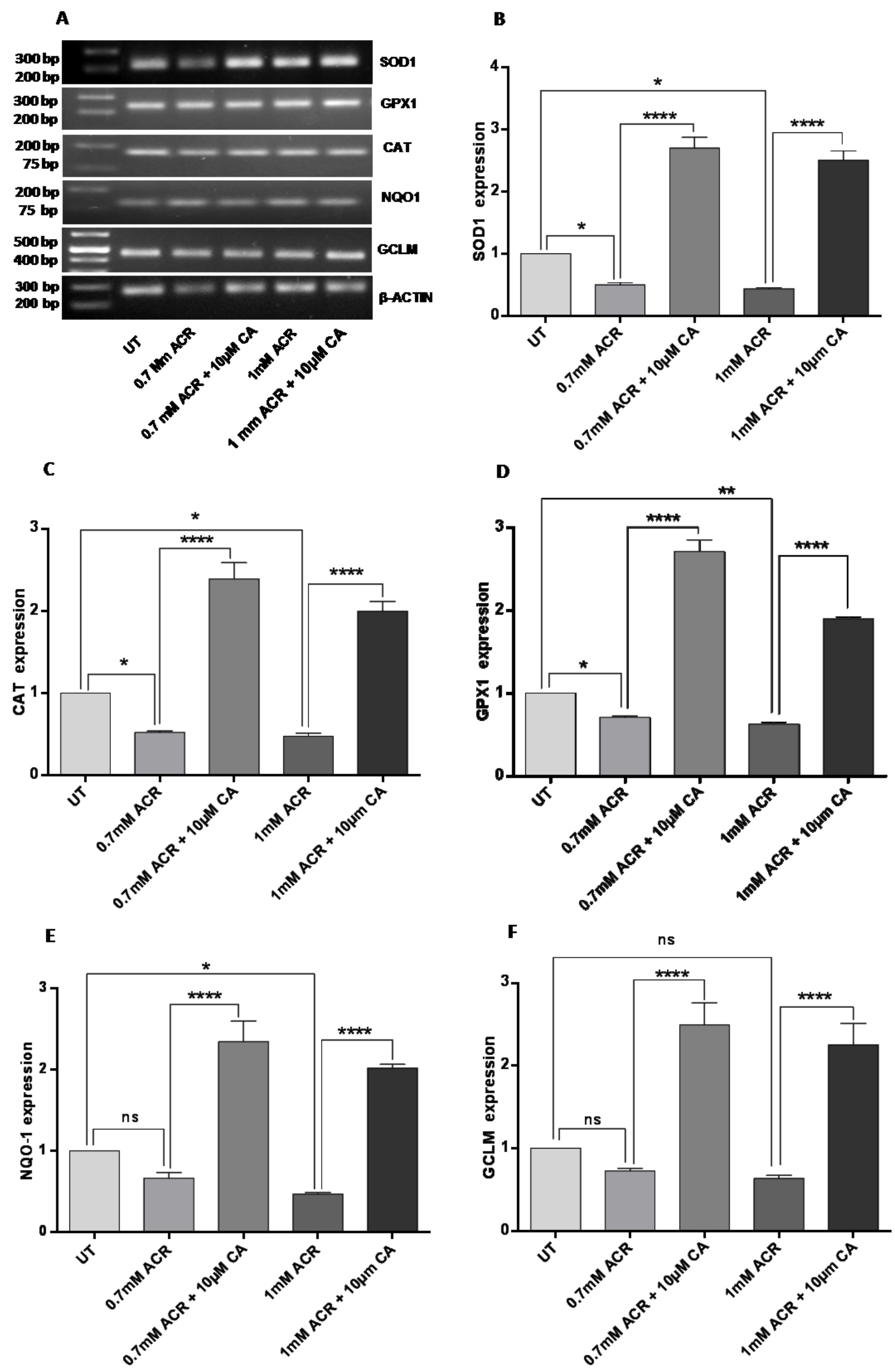
Figure 6

A

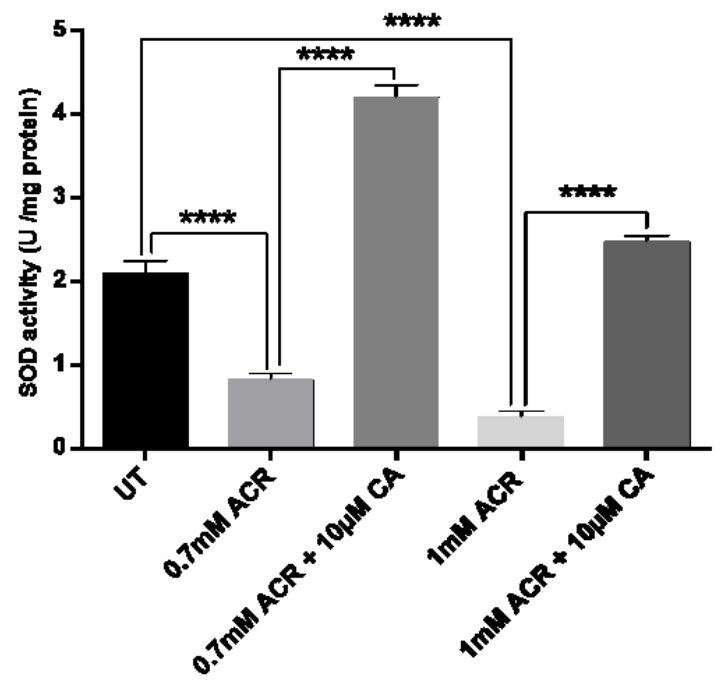

C

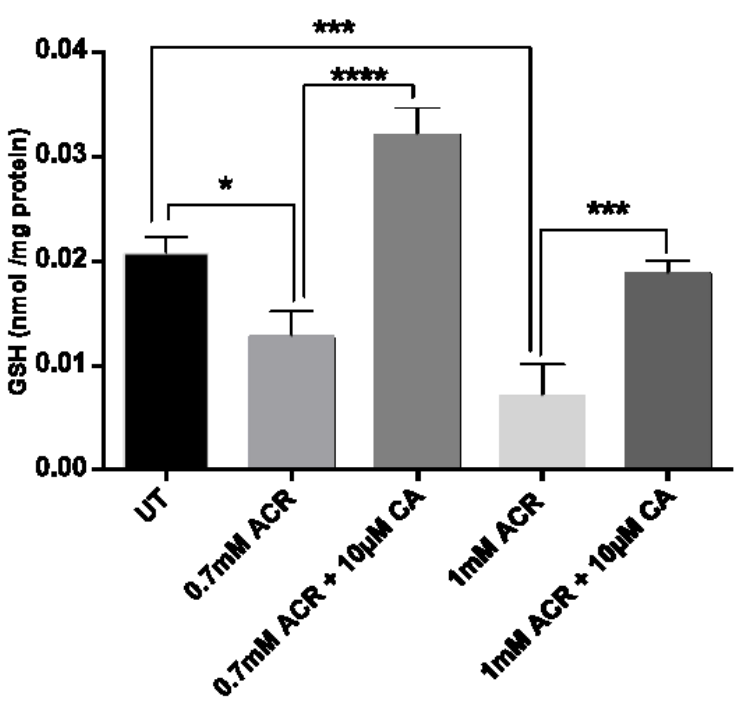

B

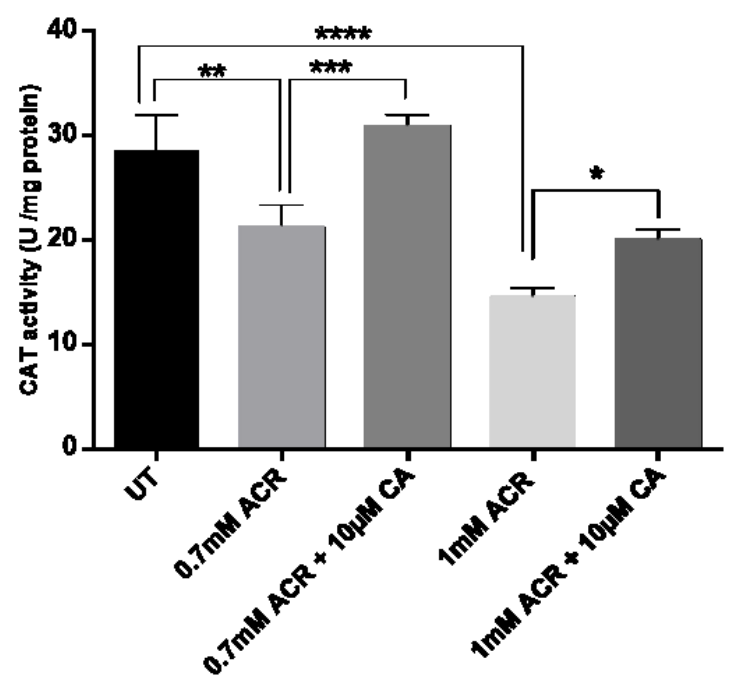

D

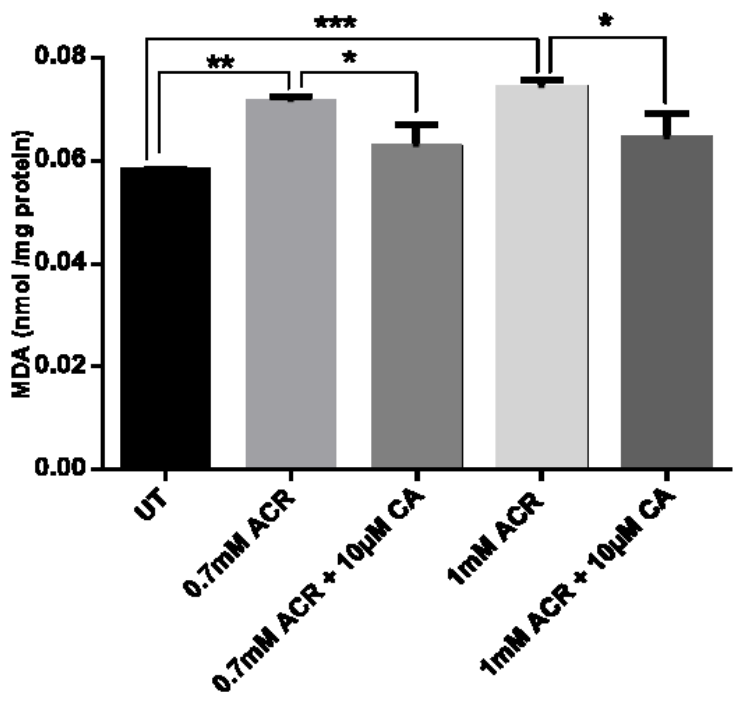


Figure 7

A

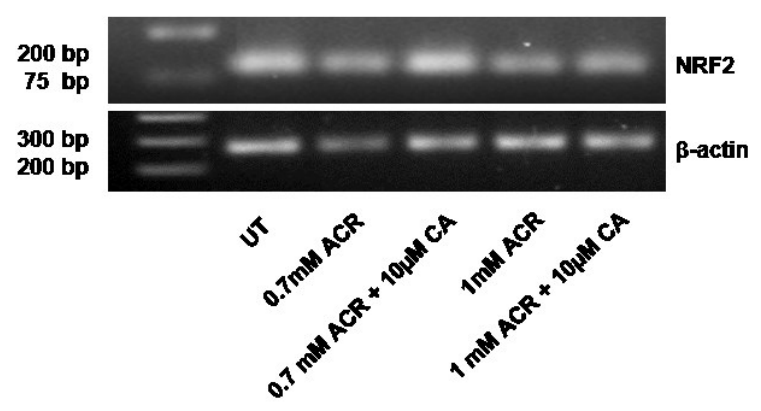

c

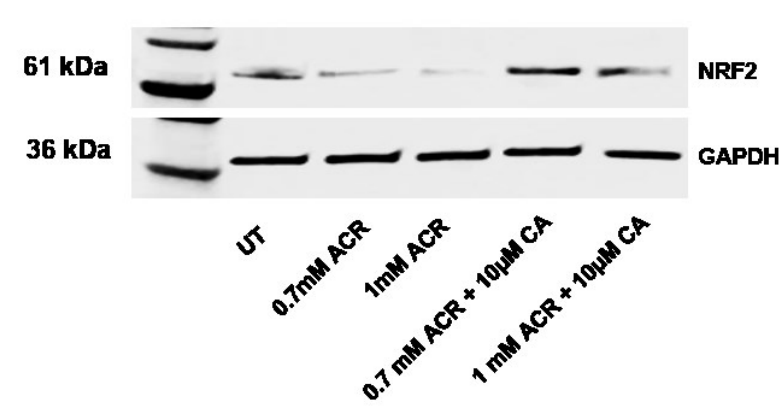

B

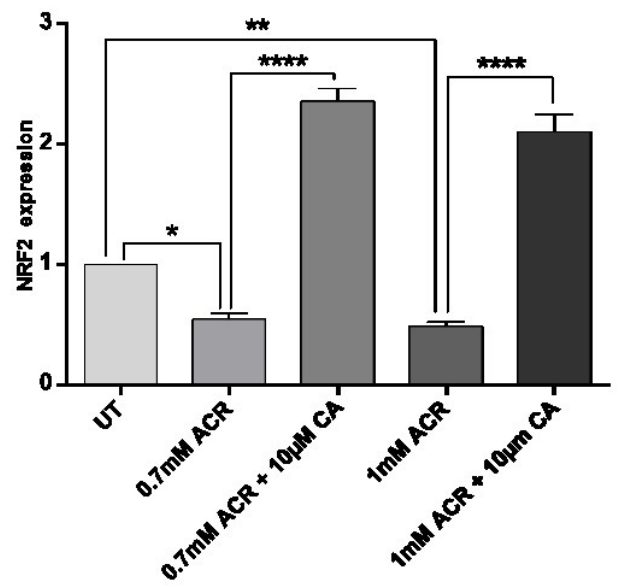

D

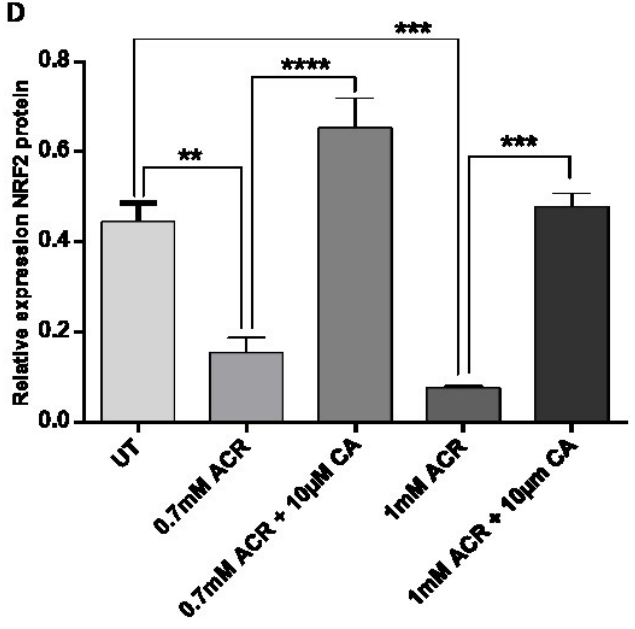

